Xia, Liyang

Associate Professor at Centre for Ibsen Studies, University of Oslo

Address: Henrik Wergelandshus, Niels Henrik Abels vei 36, 0313 OSLO,

Norway

Postal address: Postboks 1168, Blindern, 0318 Oslo, Norway

Title: A Myth that Glorifies: Rethinking Ibsen's early reception in

\title{
China
}

Author responsible for correspondence and correction of proofs:

Xia, Liyang 


\section{A Myth that Glorifies: Rethinking Ibsen's Early Reception in China}

\section{Introduction}

There is a consensus among Ibsen scholars and scholars of Chinese spoken drama that the Spring Willow Society staged A Doll's House in Shanghai in 1914 (e.g. A Ying / Qian 1956; Ge 1982; Eide 1983; Tam 1984, 2001; He 2004, 2009; Chang 2004; Tian and Hu 2008; Tian and Song 2013). In 2014, when the National Theatre in Beijing staged A Doll's House to commemorate the centenary of this premiere, ${ }^{1}$ most of the news reports and theatre advertisements cited the Spring Willow Society's prior performance. ${ }^{2}$ Scholars and journalists who write about the history of $A$ Doll's House in China agree in general not only that the performance took place but that it was the first performance of an Ibsen play in China. ${ }^{3} \mathrm{I}$ myself referred to this performance in my doctoral thesis (Xia 2013). In recent years, however, doubts have emerged not only about the claim that the Spring Willow Society performed A Doll's House, but that the Society performed any plays by Ibsen. The following scholars have asserted that there is no concrete evidence that the performance of $A$ Doll's House took place: Seto Hiroshi (2002, 2015), Huang Aihua (2001); Zhang Chuntian (2013) and Zhang Zhongliang (2006). ${ }^{4}$ The evidence that they cite, however, has received little attention from the scholars, journalists and practitioners who mention the performance in their studies of modern Chinese theatre; moreover, international practitioners and scholars working in global Ibsen studies continue to refer to the 1914 Nuola (Nora) $^{5}$ as the first performance of Ibsen in China. ${ }^{6}$ 
The aims of this essay are to explore the consensus surrounding the 1914 performance of Nuola and to consider how it has contributed to misunderstandings and biases in the studies of the early reception of Ibsen in China. This consensus has shaped not only the historical account of Ibsen in China but also that of Chinese huaju, or spoken word drama. If A Doll's House was not performed in 1914, then clearly the whole subject of Ibsen's early reception in China needs to be reconsidered, including the important subjects of Chinese resistance to the assimilation of Ibsen in the 1910s and 1920s; Ibsen's supposed centrality in the history of Chinese modernity; and the role of Japan as a conduit of Western theatre culture to China.

\section{The consensus around Spring Willow's Nuola performance}

The fact that many Chinese titles have been used to translate A Doll's House increases the difficulty of researching the production history of the play. The most common titles are Nuola 娜拉 and Wan'ou Zhijia 玩偶之家; other names include Renxing Zhijia ${ }^{7}$ 人形之家, Wan'ou Jiating ${ }^{8}$ 玩偶家庭, Kuilei Jiating ${ }^{9}$ 傀儡家庭 and Jiao $\mathrm{Qi}^{10}$ 娇妻. Elisabeth Eide suggests that Yuan Ou 怨偶 may be another title $(1983,98)$, but the plot of Yuan Ou, as described in Xinju Kaozheng Baichu 新剧考证百出 [Research on One Hundred New Drama Plays] (Zheng 1919), indicates that this refers to an entirely different play. ${ }^{11}$

The earliest scholarly accounts of the Spring Willow Society's Nuola performance appear in two books: Jindai Zhongguo yishu fazhan shi 近代中 国艺术发展史 [The History of the Development of Art in Modern China] by Yang Cunren et al. (1936); ${ }^{12}$ and Zhongguo Xiju Shi 中国戏剧史 [The 
History of Drama in China] by Xu Muyun ([1938] 2008). ${ }^{13}$ Both books contain incomplete lists of plays performed by the Spring Willow Society in Shanghai and include Nuola and Fuhuo (Resurrection by Leo Tolstoy); I have been unable to verify either performance. Neither author provides source material for their lists, or exact dates for performances. The only indication that they provide is that these two plays were performed during a time span of "less than a year" prior to the death of Lu Jingruo, Spring Willow's lead member, in 1915 (Yang 1936 [Drama section, 11]; Xu 2008, 128). There is no evidence to suggest that either author had any first-hand experience of the performances in question. ${ }^{14}$

There are no other accounts of the Spring Willow's Nuola performance in major scholarly works on the history of Chinese drama published before 1936. Judging from the list of performances in Yang's and Xu's books, it seems likely that these titles come from a memoir written by Ouyang Yuqian ([1933] 2014), a former member of the Spring Willow Society. ${ }^{15}$ But while Nuola is mentioned in Ouyang's memoir, it is in connection with a wish that he shared with Lu Jingruo to stage the play, ${ }^{16}$ thus implying that they were not able to realize their plan (Ouyang 2014, 85).

In July 1956, during a speech given on the $50^{\text {th }}$ anniversary of Ibsen's death, Tian $\operatorname{Han}^{17}$ stated that Ibsen was introduced to China in 1913 through Spring Willow Society's performance of A Doll's House (Tian 1956, 6). He provided no source for this claim and he is not quoted in later scholarship the year 1913 never came up again in any scholarship on Ibsen's premiere in China. Rather it is an article by A Ying ${ }^{18}$ suggesting that the Spring Willow Society staged A Doll's House in 1914 that appears in most of the 
documentation I have examined. A Ying wrote this article, “Ibsen's Works in China," 19 two months after Tian Han's speech; in it, he notes that Lu Jingruo published an article on Ibsen in the inaugural issue of Paiyou Zazhi 俳优杂志 (Actors’ Magazine) (1914) “during the time when Spring Willow Society was performing A Doll's House"20 (A Ying / Qian 1981, 739). Yet there is no reference in this article by Lu Jingruo to an actual performance or planned performance by Spring Willow of an Ibsen play. In his brief history of Western drama that Lu provides in the six-page article, ${ }^{21}$ the only reference to Ibsen is that he is a "strong opponent to Shakespeare" and “master player of theatre revolution" $(1914,6)$. The same magazine contains six theatre reviews, three of which were about performances by the Spring Willow Society. None of these reviews mentions A Doll's House, or any other play by Ibsen. A Ying's inference that Lu wrote the article "during the time [italics mine] when Spring Willow Society was performing A Doll's House" is not substantiated; therefore it cannot be considered evidence that the performance took place.

There was a scarcity of scholarship on Ibsen's early reception in China until the 1980s (see, e.g., He [2013]), when scholars such as Elisabeth S. Eide (from Norway) and Tam Kwok-kan (from Hong Kong) published their comprehensive studies on the staging of Ibsen plays in China. In her essay of 1983, "Huaju Performances of Ibsen in China," a survey of Ibsen performances in China before $1949,{ }^{22}$ Eide points out that "it is still not proved that Ibsen was played in the early stages of the Wenmingxi"; nevertheless she concludes that "Ibsen was included in the repertoire in the Wenmingxi era." 23 This assertion is based on her belief that "members of the Chun liu she (Spring Willow Society) must have watched performances 
of his plays in Japan" (97-98). Furthermore, Eide finds it "natural to assume that it [A Doll's House] was acted as mubiaoxi [improvised performance based on a synopsis instead of a detailed script] with a random cast and utilizing Japanese translations for their rough outline of the plot" (99) because there was no known Chinese translation of $A$ Doll's House at that time. She also refers to Lu Jingruo's article of 1914, which leads her to conclude: "Since they (the Spring Willow Society) found it worthwhile to introduce him [Ibsen] it seems highly probable that they also staged him" (98). In 1997, Eide published another essay, "Henrik Ibsen and Reforms in Chinese Drama," in which she reiterates the opinion from her 1983 essay regarding Spring Willow's involvement in staging Ibsen's plays.

Eide's 1983 essay was written after a field-trip to China in February-March, 1982, where Eide interviewed scholars and practitioners about Ibsen performances. All the interviewees whom she references maintain that the Spring Willow Society staged Ibsen's A Doll's House in Shanghai. Ge Yihong $^{24}$ and A Ying ${ }^{25}$ are among these sources. Although most of Eide's informants claim that the performance happened in 1914, one of them gives an approximate date of 1913-1914 (1983, 98); no explanation is provided for the discrepancy.

Eide does not refer to the 1936 account by Yang Cunren, even though one of her informants does mention Yang's incomplete list of Spring Willow performances. ${ }^{26}$ Instead, Eide refers to the list of plays included in Ouyang Yuqian's essay "Memories of Spring Willow" (1984) and points out that none of the known names for A Doll's House is included. For this reason, Eide speculates that the title Yuan $\mathrm{Ou}$ in Ouyang's list might be a "more 
likely candidate for the Chinese version of $A$ Doll's House" although she gives no further justifications for this conclusion. ${ }^{27}$

According to Ouyang, Yuan $\mathrm{Ou}$ is one of the plays in Spring Willow's repertoire that belongs to a category of plays based on Spring Willow members' "own ideas. . . with detailed outline and important dialogues, but without complete scripts" (Ouyang 1984, 40). Other categories include "purely translated plays," "plays adapted from foreign plays," and "plays adapted from foreign novels," all of which would be more likely to contain A Doll's House. Ouyang's list contains no reference to any translation or adaptation of A Doll's House, and judging from the plot of Yuan $\mathrm{Ou}$, which is included in Xinju Kaozheng Baichu 新剧考证百出 [Research on One Hundred New Drama Plays] (Zheng 1919), it does not resemble Ibsen's A Doll's House ${ }^{28}$.

Eide's 1983 essay relies heavily on her informants, with many of the listed sources being interviews. While she is not without some degree of skepticism regarding the statements made by her informants, she nevertheless argues that the Spring Willow performance is "highly probable" $(1983,98)$. She mentions that she spent some time in the National Library in Beijing and "received information on source-material related to performances of Ibsen" $(1983,95)$ in Nanjing and Shanghai, but she does not appear to have consulted any of the archives containing a repertoire list for Spring Willow.

Eide's investigation into the Ibsen performances in China fueled the propagation of the 1914 story by creating new "source material" for subsequent scholars. In 1982, Ge Yihong published his responses to Eide's 
questions about Ibsen performances in China in a collection entitled "Three Letters on Foreign Drama in China," 29 which were subsequently cited as the major source in Tam's study of the 1914 performance in Ibsen in China: Reception and Influence $(1984,164)$. Ge provides brief accounts of six stage productions of Ibsen's plays from 1914 to 1935 in one of the letters. He states that "the New Drama Society indeed performed Kuilei Jiating (i.e. A Doll's House) in 1914 in the name of Spring Willow Theatre at an old rental theatre" and that the play "was only performed a small number of times" due to low attendance, and therefore "did not leave any great effect in China" (Ge 1982, 66). Ge made similar statements in his 1995 essay, "Ibsen: A Link between Chinese and Norwegian People." No source is provided for his responses to Eide, but since Ge was one year old in 1914, his account cannot come from first-hand experience, and it is likely that it was based on one of the earliest and most authoritative books on the early spoken drama, Zhu Shuangyun's Xinju Shi 新剧史 [History of New Drama] (1914). The latter mentions that two of Spring Willow's 1912 performances "sold just a few seats," but neither of these performances is said to be that of A Doll's House or any other Ibsen play (Zhu 1914, 20\&26).

Eide's investigation into the reception of Ibsen in China started with her Master's thesis in 1973, which led her to continue research into this relatively uncharted field. Subsequently, scholars such as Tam Kwok-Kan (1984, 2001), Wang Zhongxiang (2000), Shuei-may Chang (2004), He Chengzhou (2004), Wang Ning (2003, 2013) and Zhang Chuntian (2013) have all written extensively in English and Chinese about Ibsen's reception in China. Many of them reiterate the claim that the Spring Willow Society performed $A$ Doll's House in 1914 . The sources they cite are usually Ge 
Yihong's “Three Letters" of 1982 and A Ying's article of 1956. These multiple references to the 1914 Spring Willow performance in scholarly works on Ibsen and huaju have turned it into a milestone in the history of Chinese spoken drama. Tian Benxiang and Hu Zhiyi’s Zhongguo Huaju Yishu Tongshi 中国话剧艺术通史 [Comprehensive History of Chinese Huaju Art] (Vol.1) (2008, 83), Tian Benxiang and Song Baozhen's Zhongguo Huaju Bainian 中国话剧百年史述 [One Hundred Years of Chinese Huaju] $(2013,77)$ and Li Xiao’s Shanghai Huaju Zhi 上海话剧志 [The History of Shanghai Huaju] $(2002,15)$ all mention the performance without citing sources. These scholars' works have been treated as authoritative by other scholars, theatre practitioners, and the popular media both inside and outside China, and with each iteration the conviction that this event took place has become stronger.

\section{The case against the 1914 Nuola performance}

In recent years, scholars in China and Japan have begun to question whether Spring Willow was responsible for the first performance of Ibsen in China. Huang Aihua from Hangzhou Normal University, who has published widely on Chinese modern drama and its relationship to Japanese modern drama, conducted an extensive investigation into the Spring Willow repertoire. Huang's research shows that there is a clear link between the Japanese shinpa plays — whether originally written by Japanese playwrights or translated and adapted from Western literary works - and the early Chinese spoken drama. In Zhongguo Zaoqi Huaju Yu Riben 中国早期话剧与日本 [Early Chinese Huaju and Japan] (2001), Huang claims that Lu Jingruo, the leading member of Spring Willow Society, failed to perform any Ibsen play 
in China $(2001,118)$. In our email correspondence, she confirmed that her extensive research into the repertoire of Spring Willow Society provided no evidence that an Ibsen play had been performed by the company.

Huang's view echoes those of Seto Hiroshi, the author of numerous books and articles on the Japanese influence on the development of Chinese spoken drama. According to his research, which includes the study of theatre advertisements published in Shenbao 申报 [Shanghai News], ${ }^{30}$ the Spring Willow Society "never performed Nuola" $(2002,86)$.

Huang Aihua's article “Studies on the Japanese Shinpa Repertoire Staged by Spring Willow Society" (2005) and her book Early Chinese Spoken Drama and Japan (2001), together with Seto's studies, are the most authoritative studies on the Spring Willow repertoire. In the documents they consulted, there were no references to Ibsen plays, or adaptations of Ibsen's plays, either by Spring Willow or any of the other major wenming $x i$ companies. $^{31}$

The remaining scholars who also claim that Spring Willow never staged Ibsen's $A$ Doll's House refer to the memoir by Ouyang Yuqian, who states that both he and Lu Jingruo had wanted to perform Ibsen, but that their plans never came to fruition $(2014,85) .{ }^{32}$ The scholars point out that although Lu Jingruo wrote an article introducing Ibsen, neither he nor his fellow Spring Willow Society members performed his plays (Zhang 2006, 87; Zhang 2013, 16). There are four places in Ouyang's memoir where Ibsen or his works are mentioned, two of which are about staging Ibsen's plays. At one point, Ouyang writes that Spring Willow members were forced to choose plays based on box office considerations to keep the 
theatre financially solvent. The bestselling shows were those like Orchid in the Empty Valley ${ }^{33}$ and stories from The Red Mansion. ${ }^{34}$ He mentions that “plays like Resurrection 35 and Nora were/are/would be/will be especially no good for making money" $(2014,66)$. Tense, as is the case here, is often not indicated by Chinese verbs, and without the contextual background it can be difficult or impossible to know whether Ouyang is speaking of something in the past, the present or the future. Thus, the wording could mean that Ouyang and Lu staged A Doll's House but it proved to be bad for business; or that they never put on A Doll's House because they knew it would not appeal to their audience. Scholars such as Yuan Guoxing $(2000,100)$ and Zhou Yunlong (2014) have interpreted Ouang's comment as proof that Spring Willow performed A Doll's House. ${ }^{36}$ However, at another point in his memoir, Ouyang writes, "Jingruo at the time was very eager to perform Nora and The Wild Duck, and I was very eager to perform Resurrection and Salome... . We were only thinking [about performing these plays], and sitting face to face happily chatting about them, but never fulfilled [our wishes to perform those plays]... . I even went crazy once and wanted to play Hedda Gabler. I really liked the thing with the two pistols. But it did not come to fruition either" $(2014,85)$. This is the evidence that Zhang Chuntian and Zhang Zhongliang point to when they deny the 1914 performance. Considering that there is no supporting evidence that Spring Willow staged either Resurrection or Nora (Seto 1988-1990, 2002, 86; Huang 2001), I conclude that it was highly unlikely that the Spring Willow Society performed Ibsen.

\section{Some neglected sources}


One probable reason why there has been no response from Chinese or nonChinese Ibsen scholars to the position held by Seto, Huang, Zhang and Zhang is that any further investigation into a possible staging by Spring Willow Society of A Doll's House would require a thorough study of the repertoire of the theatre group, as well as extensive research on the repertoire of wenming $x i$ in general. Studies on the repertoire of wenming $x i$ groups traditionally rely on several sources: ${ }^{37}$ early history books about wenming xi published before $1949,{ }^{38}$ newspapers and magazines that publish theatre announcements and reviews during the wenming xi era, memoirs by members of wenming xi groups, and authoritative books on the history of wenming xi and Chinese huaju in general published after 1949. The last group lacks any verifiable evidence regarding the 1914 performance of A Doll's House. The second and third sources have been covered by scholars who deny the 1914 performance. My investigation into the first group of sources, particularly Хinju Kao 新剧考 [Studies on the New Drama] by Fan Shiqu 范石渠 (1914), ${ }^{39}$ Xinju Shi 新剧史 [The History of New Drama] by Zhu Shuangyun 朱双云 (1914), ${ }^{40}$ Xinju Kaozheng Baichu 新剧考证百出 [Research on One Hundred New Drama Plays] by Zheng Zhengqiu 郑正秋 (1919), ${ }^{41}$ and Chuqi Zhiye Huaju Shiliao 初期职业 话剧史料 [Historical Material about Early Professional Spoken Drama] by Zhu Shuangyun 朱双云 (1942), ${ }^{42}$ have not yielded any evidence of a performance of A Doll's House during the wenming xi era.

It seems clear that scholars have associated the Spring Willow Society with Ibsen's A Doll's House mainly because Lu Jingruo had shown great interest in this play and Ibsen's work in general. Both Lu's article of 1914 and the 
references to Ibsen in Ouyang's memoir are proof of this interest, which has usually been attributed to the influence of the Japanese New Drama movement. Lu Jingruo spent some time in Japan and was a member of the cast of Shimamura Hōgetsu's production of A Doll's House in 1911, the famous production in which Matsui Sumako played Nora (Sato 1966; Huang 2001, 117-118; Wei 2005, 202; 2012, 66-67). ${ }^{43}$ According to Wei Mingjie, Lu Jingruo participated in all the performances of Shimamura's $A$ Doll's House, including rehearsals and public showings (Wei 2005, 2012). Lu's participation in the 1911 Japanese production of A Doll's House and his involvement with Bungei Kyokai ${ }^{44}$ in general can explain why he and the other members of the Spring Willow Society were so enthusiastic about Ibsen's plays. However, Huang claims that Lu Jingruo "was not able to present any of the plays by Shakespeare or Ibsen that he learned from Tsubouchi Shōyō ${ }^{45}$ after he came back to China" $(2001,118)$.

In summary, I agree with the comment by Eide, made 35 years later, that no proof has been found for the 1914 performance of A Doll's House by the Spring Willow Society. However, I would weigh the record differently, arguing that the lack of evidence makes it highly unlikely that the performance took place. Although it is true that "absence of evidence is not evidence of absence," and therefore we cannot say categorically that this performance did not happen, it is clear that the alleged event left no footprint in the history of Chinese huaju—no advertisement, review, debate, or image that attests to its existence.

\section{When was Ibsen first performed in China?}


What is the first Ibsen performance in China, if it is not Spring Willow's A Doll's House in 1914? Since the 1980s, a few lists of Chinese stage productions of Ibsen's plays have been published (Eide 1983, 1987, 1997; Tam 1984, 2001; He 2004), but they do not agree. Tam's list of 2001 (25 entries) is the most comprehensive, with references for most of the performances, but it is still missing a few entries from the list compiled by He in 2004 (17 entries) and Eide in her 1997 article. $^{46}$ These scholars all include the 1914 performance as the first Ibsen performance in China. Tam and He list the performance of $A$ Doll's House in 1923 by Women's Normal College in Beijing as the second, ${ }^{47}$ while Eide does not mention this performance in any of her essays. ${ }^{48}$

According to my research, the strongest contender for the first Ibsen performance in China is the performance of $A$ Doll's House given by the Women's Normal College in Beijing 北京女子高等师范学校. ${ }^{49}$ Several reviews appeared of the performance, which took place on May 5, 1923 (e.g. Ren 1923; Chen and Xu 1923; He 1923; Fang 1923).

\section{Remapping the early reception of Ibsen in China}

Having argued that the Spring Willow performance of $A$ Doll's House in 1914 is a critical myth, I will now examine some of the consequences of the myth in the work of scholars who have accepted it. My aim is to re-chart the history of the early reception of Ibsen as well as the dominant conception of the emergence of huaju in China, both of which have been heavily informed by an event that probably never happened. My account foregrounds the challenges involved in the assimilation of Ibsen into China during the 1910s and 1920s; suggests the need to reconsider the Japanese influence on this 
assimilation process; and questions the centrality of Ibsen in the modernization of Chinese theatre.

\section{Commercial, aesthetic and ideological challenges}

A common way in which scholars describe the 1914 Nuola performance in China is to emphasize its "earliness": A Doll's House was staged in China “as early as in 1914” (e.g. Song 2007, 19; Zhang Lushi 2006; Sun 2016, 74). This creates a narrative in which Ibsen and the Spring Willow Society, the first and most respected professional huaju group, together pioneered the modernization of Chinese theatre by staging Ibsen's plays against all the commercial, aesthetic and ideological challenges current in 1914. The alternative account suggests that Ibsen was not staged until 1923 precisely because of these challenges, in particular the prevailing aesthetic preferences of Chinese theatre audiences, which shaped the professional work of a theatre group such as the Spring Willow Society, despite its high aspirations.

Huang Aihua attributes the absence of Ibsen in Spring Willow's repertoire to "the limitations of the circumstances" $(2001,118)$. She does not elaborate on these "limitations" apart from saying that it was "not Lu Jingruo's personal fault" but rather "the tragedy of that time" $(2001,119)$. Similar references to unspecified limitations appear in the work of other scholars, such as Ge Yihong's “Three Letters” (1982), Seto Hiroshi's research on the historical phases of wenming xi (2006), and Zhu Shuangyun's Historical Material about Early Professional Spoken Drama (1942). Zhu's opening description of the Spring Willow Society (under the name The New Drama Fellowship) reads as follows: "The New Drama Fellowship ${ }^{50}$ was, without a 
doubt, the only drama group that does not cater to the taste of the middle and lower social classes by performing low brow comedy; . . instead they lead the audience with their artistic spirit" $(1942,22)$. In The History of the Development of Art in Modern China, Yang Cunren claims that Spring Willow Society's talents were incomparable among all the new drama groups and that they served as "a strong force in correcting the perils [of new drama] at the time" (1936, 11-12). However, the absence of Ibsen in Spring Willow's documented repertoire paints a rather different picture than the official discourse on this highly acclaimed wenming xi group: the strong forces resisting the theatre of ideas may have affected this group just as much as "lesser" groups. Members of the Spring Willow Society were subjected to the same commercial pressures and may have chosen to steer away not only from Ibsen, but also from other playwrights whose work did not fit the aesthetic preferences of theatre goers in the 1910s.

It is possible that it was not until the succeeding theatre movement- - the Amateur Theatre Movement (“爱美剧”运动) ${ }^{51}$ in the 1920s- that Ibsen appeared on the Chinese stage. According to Yang, the demise of wenming $x i$ was directly related to the fact that it was produced by professional theatre groups $(1936,12-13)$. Relying on the theatre to make a living forced the actors to cater to the tastes of their audiences and produce work with an accessible comic sensibility. The solution to this dilemma was the establishment of a theatre completely outside commercial entertainment. Ibsen's plays were staged by many different amateur student theater groups during this period, the first of which (that is fully documented) is the 1923 Nuola by Women's Normal College in Beijing, a member of the New China Drama Association 新中华戏剧协社, established by Chen Dabei (1887- 
1944) and Pu Boying (1875-1934). By then, three translations of A Doll's House had been published, ${ }^{52}$ and according to the critic Ren Tuo, the performance faithfully followed Pan Jiaxun's translation (1923).

The audience's response to the performance in 1923 reveals an added dimension to the complex reception of Ibsen in Chinese theatre because the critical question focused on whether the play's value lay in its moral teachings or in its aesthetics. ${ }^{53}$ There was a heated debate in which some critics thought that the students' efforts should be applauded for promoting Western drama in China, while others felt that the subtlety of art was missing in the performance. According to some of the reviews, some spectators (perhaps even the majority of the audience) left the performance before its end. Apart from this being an illustration of the "viewing behavior of the [traditional theatre] audience" (Ren 1923), which was bemoaned by many critics, there were also intellectual devotees of modern drama who left the performance because of the "amateurish" acting and a lack of "aesthetic pleasure" in the production (Chen and Xu 1923). These intellectuals included Chen Xiying and Xu Zhimo, who insisted that "the lasting value of Nora lies in its art" and that "if we only discover the moral teaching in the play, we will miss the subtlety of art." Chen and Xu both became members of the short-lived National Theatre Movement in 1925/1926, which sought to counter the "Ibsen-based socio-critical tilt" in the development of Chinese spoken drama (Liu 2016, 19).

Liu Siyuan, in his article on the National Theatre Movement (2016), points to the attacks by leading members of the movement such as Yu Shangyuan, Wen Yiduo and Zhao Taimou on Ibsen worship in China: they felt that it "was the wrong track and led to mediocrity" (Liu 2016, 11). Instead, they 
advocated a "different trajectory for huaju that hybridized Western and indigenous performance elements" (27). Indeed, the dominance of Ibsen in the discourse of the New Culture Movement worried even Tian Han, a selfproclaimed "budding Ibsen in China,"54 and in his 1922 translation of Hamlet, he promoted Shakespeare as an antidote to the Ibsen influence (Tian 1922, 1). This rejection of Ibsen and theatrical realism, though brief, signifies yet another force that was countering the early reception of Ibsen in the 1920s, coalescing into an ideological war between "art for art's sake" and "art for life's sake." Liu points out that "the factional Beijing media sphere of the warlord era ... paradoxically gave longer-lasting voice to the students than their professors" (Liu 2016). The professors who had been educated in the United States and Britain lost this ideological war to students imbued with the aversion to traditional theatre current within the New Cultural Movement. Ibsen's adoption by the students' amateur theatre marks the beginning of the ideological use of his plays in Chinese theatre.

\section{Japanese influence on the Ibsen tradition in Chinese theatre}

Not only does the alternative account of Ibsen's first performance highlight the challenges and resistance that Ibsen faced in the early years of Chinese huaju, it also changes our understanding of the pathway by which Ibsen was introduced into China. It has been well documented that the Japanese shinpa theatre had a strong influence on early Chinese spoken drama (Tam 1984; Huang 2001; Liu 2006; Seto $2015^{55}$ ), and it has been accepted that Ibsen was introduced to Chinese theatre through Japan, which assimilated his plays through German and English translations (Kano 2001, Sato 1962). This would still hold true despite the absence of Ibsen in Spring Willow's 
repertoire because the earliest mentioning of Ibsen in Chinese literary and theatre circles was by Lu Xun (1908) and Lu Jingruo (1914), both educated in Japan; and the Japanese production that Lu Jingruo appeared in used Shimamura Hōgetsu's translation from the German. ${ }^{56}$ But it is also the link between Spring Willow and Japan and its causal connection to the unverifiable 1914 performance that the authors of A Global Doll's House cite as an example of how actress managers (in this case Matsui Sumako) played crucial roles in the global dissemination of Ibsen in the late nineteenth and early twentieth centuries; although Matsui did not play Nora in China, the influence of her production in Tokyo, via Lu Jingruo et al., resulted in Spring Willow's performance of $A$ Doll's House in Shanghai (Holledge et al. 2016, 47). Thus the authors of A Global Doll's House have unintentionally silenced the pioneering woman who may well have been responsible for the first production of the play in China because the Japanese influence from Matsui's 1911 performance disappears when the Spring Willow's performance is replaced by a production mounted by the Amateur Theatre movement, a theatre practice directly imported from the West. In addition, the 1923 performance followed the publication of three Chinese translations based on English versions of the play-more precisely William Archer's translation-which came directly from the Norwegian text.

\section{Ibsen's centrality in Chinese modern theatre}

Does the alternative narrative of a much later Ibsen debut in Chinese theatre also destabilize Ibsen's centrality in the emergence of Chinese huaju and, in turn, the modernization of Chinese theatre? 
He Chengzhou bestows a great deal of importance on the alleged 1914 performance in his 2009 article on Ibsen performances in China, asserting that this was "the first Chinese performance of Ibsen, and of modern Western playwrights in general" (He 2009, 118). He goes on to claim that "Ibsen has continued to be the most frequently performed foreign playwright in China," thus stressing Ibsen's centrality to the theatre modernization process. At the end of the article, he includes an appendix of 25 Ibsen productions presented in China (from 1914 to 2008), stating that this is an underestimation because of the loss of performance records due to wars and political turmoil, and the fact that large numbers of Ibsen performances were by amateur groups who received limited critical attention. (This could equally be said regarding the documentation of Shakespeare in China, but Li Ruru has published an equivalent list of 125 performances from the wenming xi era to 2001 (Li 2003, 231-240). The question here is whether Shakespeare should also be considered a major foreign influence in accounts of the modernization of Chinese theatre since his plays were adapted into multiple Chinese stage and screen genres during the twentieth century.)

If the 1914 production of $A$ Doll's House did not take place, George Bernard Shaw's Mrs. Warren's Profession becomes the first verifiable Western realist play to be staged in China. It was produced by Shanghai New Stage 上海新舞台 in October 1920 - after months of preparation and substantial financial investment. ${ }^{57}$ Judging from the cast list, this was an allmale commercial production, advertised as "the very first staging of a Western realist play in the Chinese theatre" (Wang 1920, 1921). This claim, if true, would be an almost contemporaneous refutation of the 1914 myth 
and prove that the first modern realist playwright to enter Chinese theatre was Shaw, the fervent Ibsenite. ${ }^{58}$ This complicates the story of Ibsen's influence over the early Chinese huaju theatre, not because the 1920 premiere of Mrs. Warren's Profession was a box office success, but rather because it was a failure due to similar commercial, aesthetic and ideological reasons analyzed above. In fact, the decision to perform Shaw's play was probably due to the introduction of Ibsen's work into Chinese literary circles, which initiated a fever for "problem plays" in Chinese theatre. Tian Han reads Mrs. Warren's Profession as a reaction and "answer to Ibsen's Doll's House" because it suggests economic independence as a solution for the new woman (Tian 1956). ${ }^{59}$

\section{Conclusion}

This essay is the result of an investigation into the dominant narrative regarding the reception of Ibsen in China, including the problematic existence of what is commonly claimed to be the first Ibsen performance in Chinese theatre. My analysis has shown that there is no evidence to support a Spring Willow Society performance of A Doll's House in 1914, and that even if this performance did occur, it left no discernable footprint or impact. Instead, the first fully documentable Ibsen performance in China, supported by theatre announcements and reviews, is the 1923 performance of $A$ Doll's House by the female students at Beijing Women's Normal College.

My analysis has revealed how the myth of this single performance has supported faulty discourses concerning the importance of Ibsen and the Spring Willow Society in Chinese theatre; the Japanese influence on Chinese huaju; the centrality of the May Fourth Movement in China; and, 
the canonical position of a Norwegian playwright in China, and, ultimately, in world theatre.

Within the internal politics of China, the Spring Willow Society performance is part of the history of the May Fourth movement, an ideological heritage that the Chinese Communist Party (CCP) still fiercely protects. Ibsen is part of modern China's linear, evolutionary national history—a history that secures a "false unity of a self-same, national subject" (Duara 1995, 4). The nation's strong and often implicit ideological guideline has ensured that a politically charged figure such as Ibsen is not represented by multiple voices. The significance of this potentially mythical performance ties Ibsen scholarship to the official CCP discourse. Triggered by recent scholarly works that examine the history of Chinese huaju (Seto, Huang, Zhang and Zhang), this article suggests an alternative account that puts Ibsen's first appearance on the Chinese stage nine years later than previously claimed. It points to the otherwise overlooked nuances and complexity in the reception of Ibsen and questions the centrality of Ibsen and the Spring Willow Society in the history of huaju. In addition, this new account reduces the impact of Japan on the introduction of Ibsen to China, and contests the narrative of Chinese huaju history that is seen as coeval with Japanese theatre modernization.

Outside China, within the historiography of world theatre, the 1914 myth has functioned as a pillar in the story of the global dissemination of Ibsen. The exoticism that lies in an improvised Ibsen performance with an all-male cast in early twentieth-century China has made this myth popular with 
international scholars. In light of the new account, a re-examination of the involvement of women in the history of Ibsen and Chinese theatre is due. 
References

A Ying / Qian Xingcun 阿英/钱杏村. (1956) 1981. “易卜生的作品在中国” [Ibsen's Works in China]. In 阿英文集 [Collected Essays by A Ying], 738743. Beijing: Sanlian Publishing House.

Chang, Shuei-may. 2004. Casting Off the Shackles of Family: Ibsen's Nora Figure in Modern Chinese Literature, 1918-1942. New York: Peter Lang Publishing Inc.

Chen Xiying and Xu Zhimo 陈西滢、徐志摩. 1923. “看新剧与学时髦” [Watching New Drama Plays and Following the Trend] and “我们看戏看的 是什么?”[What Are We Watching When We Watch Theatre Performances?] 晨报附刊 [Morning Post Supplement], May 20.

Duara, Prasenjit. 1995. Rescuing History from the Nation: Questioning Narratives of Modern China. Chicago: The University of Chicago Press.

Eide, Elisabeth S. 1973. "Hu Shih and Ibsen: Ibsen's Influence in China 1917-1921 as Seen through the Eyes of a Prominent Chinese Intellectual." Master's thesis, University of Oslo.

Eide, Elisabeth S. 1983. "Huaju Performances of Ibsen in China." Acta Orientalia Vol.44: 95-112.

Eide, Elisabeth S. 1987. "Performances of Ibsen in China after 1949". Chapter 13 in Drama in the People's Republic of China, edited by Constantine Tung and Colin Mackerras. New York: State University of New York Press.

Eide, Elisabeth S. 1997. "Henrik Ibsen and Reforms in Chinese Drama". Contemporary Approaches to Ibsen Vol. 9: 181-205.

Fan Shiqu 范石渠. 1914. 新剧考 [Studies on the New Drama]. Vol. 1. Shanghai: Zhonghua Publishing House. Available as e-book on Shanghai Theatre Museum's website: http://shtm.sta.edu.cn/gcjpzs/xjwx/9e9aefb2_97fd_4d33_b977_6ab7b6a55b 63.html.

Fang Xin 芳信. 1923. “看了娜拉后的零碎感想” [Random Thoughts after Watching Nuola]. Morning Post Supplement 晨报附刊, May 13.

Ge Yihong 葛一虹. 1982. “关于外国戏剧在中国情况的三封信” [Three Letters on Foreign Drama in China]. Studies on Drama 戏剧研究. Vol.12, pp.65-67. 
Ge Yihong 葛一虹. 1995. “易卜生是联系中挪人民的纽带” []. Ibsen Research Papers 易卜生研究论文集, edited by Meng Shengde and Astrid Sæther, 18-21, 238-242. Beijing: Chinese Literature Publishing House.

He Chengzhou. 2004. Henrik Ibsen and Modern Chinese Drama. Oslo: Unipub forlag.

He Chengzhou. 2009. "Interculturalism in the Theatre and Chinese Performances of Ibsen”. Ibsen Studies. Vol. 9, No. 2: 118-135. DOI: 10.1080/15021860903491983

He Chengzhou 何成洲. 2013. “新中国 60 年易卜生戏剧研究之考察与分 析” [An Investigation and Analysis upon Ibsen Drama Research in Recent 60 Years]. 艺术百家 [Hundred Schools of Art Journal] No. 1: 48-53.

He Yigong 何一公. 1923. “女高师演的《娜拉》” [Nuola by Women’s Normal College]. 晨报附刊 [Morning Post Supplement], May 18.

Holledge, Julie, Jonathan Bollen, Frode Helland, and Joanne Tompkins. 2016. A Global Doll's House: Ibsen and Distant Visions. London: Palgrave Macmillan.

Huang Aihua 黄爱华. 1993. “春柳社研究札记” [Research Notes on Spring Willow Society]. 戏剧艺术 [Theatre Arts] Vol. 2.

Huang Aihua 黄爱华. 2001. 中国早期话剧与日本 [Early Chinese Huaju and Japan]. Hunan: Yuelu Publishing House.

Huang Aihua 黄爱华. 2005. “春柳社演出日本新派剧剧目考略” [Studies on the Japanese Shinpa Repertoire Staged by Spring Willow Society]. 新文 学史料 [Historical Material on New Literature] Vol. 3.

Huang Aihua 黄爱华. 2016. “20 世纪初期报刊传媒与新剧的传播一以 《申报》学生演剧、文明新戏演出消息和广告为例” [Newspaper Media in Early $20^{\text {th }}$ Century and the Spreading of New Drama: Examples from Theatre Announcements and Advertisements of Student Performances and Wenming New Drama Performances in Shenbao]. 南京大学学报 [Journal of Nanjing University] No. 2: 128-136.

Kano, Ayako. 2001. Acting Like a Woman in Modern Japan: Theater, Gender, and Nationalism. New York: Palgrave.

Li, Kay. 2016. Bernard Shaw's Bridges to Chinese Culture. Palgrave Macmillan.

Li, Ruru. 2003. Shashibiya: Staging Shakespeare in China. Hong Kong: Hong Kong University Press. 
Li Xiao 李晓, ed. 2002. 上海话剧志 [The History of Shanghai Huaju]. Shanghai: Baijia Publishing House.

Liu Siyuan. 2006. "The Impact of Shinpa on Early Chinese Huaju”. Asian Theatre Journal, Vol. 23, No. 2: 342-355.

Liu Siyuan. 2016. "The Cross Currents of Modern Theatre and China's National Theatre Movement of 1925-1926". Asian Theatre Journal, Vol. 33, No. 1: 1-35.

Lu Jingruo 陆镜若. 1914. “伊蒲生之剧” [Ibsen’s Drama]. 俳优杂志 [Actor's Magazine] Vol. 1: 1-7.

Lu Xun 鲁迅. 1908. “摩罗诗力说” [On the Power of Mara Poetry]. 河南 [Henan] Vol. 2\&3.

McDougall, Bonnie S. 1971. The Introduction of Western Literary Theories into Modern China: 1919-1925. Tokyo: The Centre for East Asian Cultural Studies.

Ouyang Yuqian 欧阳予倩. (1933) 2014. 自我演戏以来 [Since I Started to Perform Onstage]. Shanghai: Sanlian Publishing House.

Ouyang Yuqian 欧阳予倩. (1957) 1984. “回忆春柳” [Memories of Spring Willow]. In 中国话剧运动五十年史料集 1907-1957 [Collection of Historical Materials about the Fifty Years of Chinese Huaju Movement: 1907-1957), 13-46. Beijing: China Drama Publishing House.

Qi, Shouhua. 2016. “(Mis)reading Ibsen: Chinese Noras On and Off the Stage and Nora in Her Chinese Husband's Ancestral Land of the 1930s as Reimagined for the Globalized World Today". Comparative Drama, Vol. 50, No. 4: 341-364.

Ren Tuo 仁佗. 1923. “看了女高师两天演剧以后的杂谈” [Miscellaneous Remarks after Watching Two Days of Performances by Women's Normal College]. 晨报附刊 [Morning Post Supplement], May 11.

Sato Toshihiko. 1962. "Ibsen in China". In Edda, No. 2.

Sato Toshihiko. 1966. "Henrik Ibsen in Japan”. Doctoral thesis, University of Washington.

Seto Hiroshi 濑户宏. 1988-1990. “《申报》所载春柳社上演广告” 上. 中. 下之一.下之二” [Spring Willow Society’s Theatre Advertisements Published in Shenbao]. 《长崎综合科学大学纪要》[Journal of Nagasaki Institute of Applied Science] Vol. 29, No. 1\&2 (1988), Vol. 30, No. 2 (1989), Vol. 31, No. 2 (1990). 
Seto Hiroshi 濑户宏. 2001. “新民社上演目录” [Xinmin Society’s Repertoire]. 《摄大人文科学》No. 9.

Seto Hiroshi 濑户宏. 2002. “文明戏（中国早期话剧）研究史的几个问题 一以袁国兴和黄爱华近著为中心” [Considerations in the Historical Studies of Modern Chinese Drama: A Review of Yuan Guoxing and Huang Aihua's monographs]. 杭州师范学院学报（社会科学版） [Journal of Hangzhou Teachers College (Social Sciences Edition)] Vol.5: 84-88.

Seto Hiroshi 濑户宏. 2003. “民鸣社上演目录” [Minming Society’s Repertoire]. 翠书房.

Seto Hiroshi 濑户宏. 2006. “试论文明戏历史分期和它在中国戏剧史上地 位” [On the Historical Phases of Wenming Xi and Its Place in the History of Chinese Theatre]. 戏剧艺术 [Theatre Arts] Vol.1.

Seto Hiroshi 濑户宏. 2014. “再论春柳社在中国戏剧史上的位置” [Further Discussion on the Place of Spring Willow Society in the History of Chinese Theatre]. 戏剧艺术 [Theatre Arts] Vol. 3.

Seto Hiroshi 濑户宏. 2015. 中国话剧成立史研究 [A Study on the Formation of Chinese Spoken Drama]. Translated by Chen Linghong 陈凌 虹. Xiamen: Xiamen University Press.

Shen Xi 哂溪. 2003. “《娜拉》在中国舞台的初演” [First Performance of Nuola on Chinese Stage]. 中国现代文学研究从刊 [Chinese Modern Literature] Vol. 4.

Song Baozhen 宋宝珍. 2007. “易卜生与百年中国话剧” [Ibsen and a Hundred Years of Chinese Huaju]. 中国图书评论 [China Book Review] Vol. 1: 14-20.

Sun Jian. 2016. “Ibsen and Peking Women's High Normal University”. In Ibsen between Cultures, edited by Frode Helland and Julie Holledge, 69-92.

Tam, Kwok-Kan. 1984. "Ibsen in China: Reception and Influence".

Doctoral thesis. University of Illinois at Urbana-Champaign.

Tam, Kwok-Kan. 2001. Ibsen in China (1908-1997): A Critical-Annotated Bibliography of Criticism, Translation and Performance. Hong Kong: The Chinese University Press.

Tian Benxiang 田本相, and Hu Zhiyi 胡志毅, eds. 2008. 中国话剧艺术通 史第一卷 [Comprehensive History of Chinese Huaju Art Vol. 1]. Shanxi: Shanxi Education Press. 
Tian Benxiang 田本相, and Song Baozhen 宋宝珍, eds. 2013. 中国百年话 剧史述 [One Hundred Years of Chinese Huaju]. Liaoning: Liaoning Education Press.

Tian Han 田汉. (1956) 1957. "Bernard Shaw: Master of Realist Drama [A Chinese Communist Perspective]". Bulletin (Shaw Society of America) Vol. 2, No. 3: 11-15. (An English translation of Tian's 1956 speech)

Tian Shouchang (Tian Han), Guo Moruo and Zong Baihua 田寿昌（田 汉）、郭沫若、宗白华. 1920. 三叶集 [The Three Leaves Collection]. Shanghai: Ya Dong Library.

Wan Laitian 万籁天. 1956. “排演 “娜拉” 的回忆” [Memories of Rehearsing Nuola]. 辽宁日报 [Liaoning Daily]. October 27.

Wang Fengxia 王凤霞. 2008. “重探百年话剧之源一中国话剧不始于春柳 社补证” [On the Origin of a Hundred Years of Chinese Huaju: Additional evidence for the refutation of Spring Willow Society as the origin of Chinese huaju]. 艺术百家 [Hundred Schools in Art] Vol.4: 167-170.

Wang Fengxia 王凤霞. 2008. “作为 “共名” 的文明戏一文明戏的类型和 形态” [Sharing the “Same Name": Types and Styles of Wenming Xi]. 江汉 论坛 [Jianghan Tribune] Vol.7: 112-117.

Wang Fengxia 王凤霞. 2011. ““甲寅中兴”之上海新剧团体考” [Studies on the New Drama Groups during the "Jiaying Renaissance”]. 文化遗产 [Cultural Heritage]. No. 3.

Wang Ning 2003. "Reconstructing Ibsen as an Artist: A Theoretical Reflection on the Reception of Ibsen in China". Ibsen Studies Vol. 3, No. 1: 71-85. DOI: 10.1080/15021860304322.

Wang Ning 2013. "Ibsen Metamorphosed: Textual Re-appropriations in the Chinese Context”. Neohelicon No. 40: 145-156. DOI 10.1007/s11059-0130164-2.

Wang Youyou 汪优游. 1920. “读周剑云的评《华奶奶之职业》”[After Reading Zhou Jianyun's Review of Mrs. Warren's Profession]. 时事新报 [New News Post], December 12.

Wang Youyou 汪优游. 1921. “营业性质的剧团为什么不能创造真的新 剧 ? " [Why Can't Commercial Theatre Groups Create Real New Drama Plays?]. 时事新报 [New News Post], January 27.

Wang Zhongxiang 王忠祥. 2002. 易卜生 [Ibsen]. Beijing: Huaxia Publishing House. 
Wei Mingjie 魏名婕. 2005. “陸鏡若と日本の演劇人たち” [Lu Jingruo and the Theatrical World in Meiji Japan]. 社会環境研究 [Studies on Society and Environment] Vol. 10: 187-205.

Wei Mingjie 魏名婕. 2012. “论日本新剧运动对陆镜若的影响” [The Influence of Japanese New Drama Movement on Lu Jingruo]. 戏剧艺术 [Theatre Arts] Vol. 4: 54-69.

Xia Liyang. 2013. "Heart Higher than the Sky: Reinventing Chinese Femininity through Ibsen's Hedda Gabler". Doctoral thesis. University of Oslo.

Xu Muyun 徐慕云. (1938) 2008. 中国戏剧史 [The History of Drama in China]. Shanghai: Century Publishing Group.

Yang Cunren. 1936. 戏剧 [Drama] in 近代中国艺术发展史 [The History of the Development of Art in Modern China]. Shanghai: Liangyou Publishing House.

Ying Xi 英溪. 2003. “易卜生戏剧在中国何时开始上演” [When Was Ibsen's Plays First Performed in China]. 中国现代文学研究从刊 [Chinese Modern Literature] Vol. 2: 10.

Yuan Guoxing 袁国兴. 2000. 中国话剧的孕育与生成 [The Incubation and Birth of Chinese Spoken Drama]. Beijing: China Drama Press.

Zhang Chuntian 张春田. 2013. 思想史视野中的《娜拉》一五四前后的 女性解放话语 [Nora from a Perspective of History of Ideas: Discourses on Female Emancipation around May Fourth]. Taipei: Xinrui Wenchuang.

Zhang Lushi 张璐诗. 2006. ““易卜生年”：向 “现代戏剧之父”致敬” [The Ibsen Year: Paying Tribute to "The Father of Modern Drama"]. 中国 日报网 [China Daily], March 15. Accessed 15 November 2017. http://www.chinadaily.com.cn/hqylss/2006-03/15/content 540053.htm

Zhang Xiao'ou 张晓鸥. 2015. “一场有关性别的辩证一中国舞台从女子 登台到男女合演” [A Debate about Gender: From Women Entering Chinese Theatre to Mixed Cast Performances]. 戏剧文学 [Drama and Literature] Vol. 11: 134-143.

Zhang Zhongliang 张中良. 2006. 学术时髦的陷阱 [Traps of Academic Trends]. Taipei: Xiuwei Information and Technology.

Zheng Zhengqiu 郑正秋. 1919. 新剧考证百出 [Research on One Hundred New Drama Plays]. Shanghai: Zhonghua Publishing House. Available as ebook on Shanghai Theatre Museum's website: 
http://shtm.sta.edu.cn/gcjpzs/xjwx/d602b04a_e158_478d_91b7_b631b990a 182.html.

Zhou Yunlong 周云龙. 2014. “娜拉在现代中国：一项知识的考掘” [Nora in Modern China: A Project in the Archaeology of Knowledge]. 戏剧艺术 [Theatre Arts] Vol.4.

Zhu Hengfu 朱恒夫. 2004. ““春柳社”之前的上海新剧” [New Drama in Shanghai before Spring Willow Society]. 戏剧艺术 [Theatre Arts] Vol.6: 79-83.

Zhu Shuangyun 朱双云. (1914) 2015. 新剧史 [The History of New Drama]. Beijing: Dongfang Publishing House.

Zhu Shuangyun 朱双云. 1942. 初期职业话剧史料 [Historical Material about Early Professional Spoken Drama]. Chongqing: Independent Publishing House. 
Notes:

${ }^{1}$ The National Theatre in Beijing staged the performance Wan Ou Zhi Jia from January 14 to January 29 in 2014, starring a celebrity couple Cao Ying and Wang Ban, directed by Ren Ming.

${ }^{2}$ For example, http://wap.chncpa.org/gywm/zxdt/mtsj/201608/t20160823_128600.shtml and http://wap.chncpa.org/gywm/zxdt/mtsj/201608/t20160823_128840.shtml. (last accessed September 21, 2017).

${ }^{3}$ For example, He Chengzhou's "Ibsen's Reception in China", 2006 (http://www.gmw.cn/01ds/2006-05/24/content_422277.htm, last accessed Sep 21, 2017); Hu Cuiran and Song Baozhen's “Ibsen and A Hundred Years of Chinese Spoken Drama”, 2007

(http://www.china.com.cn/culture/zhuanti/huaju/2007-

05/10/content 8231416.htm, last accessed Sep 21, 2017); Li Hongli's “The Nora Storm", 2007

(http://www.cctv.com/program/witness/topic/geography/C20323/20071225/ 102775.shtml, last accessed Sep 21, 2017) and Shi Qin'e's “The Ibsen of the World; The Ibsen of Eternity" 2006

(http://www.chinadaily.com.cn/hqylss/2006-08/24/content 673480.htm, last accessed Sep 21, 2017).

${ }^{4}$ Ying Xi (2003) and Shen Xi (2003) also argue against the popular belief in the 1914 performance. Ying Xi and Shen Xi appear to be pseudonyms. Judging from the wording, these two half-page long articles may be by the same author, possibly Zhang Zhongliang, whose three-page long essay "When Was Ibsen's Work First Performed in China?" in 2006 combined the views in these two articles from 2003.

${ }^{5}$ Nuola 娜拉 is a common Chinese name for Ibsen's play A Doll's House.

${ }^{6}$ A few scholars have mentioned the opposite opinions regarding Ibsen's first performance in China, but only briefly in passing, without giving any analysis. For example, see Zhou Yunlong (2014) and Qi (2016)

${ }^{7}$ Renxing Zhijia was used by Lu Jingruo (1914). It is a borrowed term from the Japanese translation of A Doll's House - 《人形の家》.

${ }^{8}$ Wan'ou Jiating was used by one of Elisabeth Eide's informants in her essay from 1983. I have never seen this name in the title of any translation or stage production of the play.

${ }^{9}$ Kuilei Jiating was used by Chen Jia in his translation of the play in 1918 and by Ouyang Yuqian in his translation/adaptation in 1925.

${ }^{10}$ Jiao Qi (Charming Wife) is the title of a two-page synopsis of the play by an author named Le Shui, published in the Short Story Magazine in 1915. 11 For the plot summary, see Note 28.

12 《近代中国艺术发展史》The book contains five sections on different aspects of art in modern China: arts and crafts, music, paintings, drama and films - each written by a different author. The drama section is authored by Yang Cunren 杨邨人 (1901-1955).

13 中国戏剧史, authored by Xu Muyun 徐慕云 (1900-1974). This book covers the history of Chinese drama over the span of over two thousand years. The section on wenming $x i$ has a strikingly similar wording to Yang Cunren's writing, without crediting Yang. Xu gives a list of five plays that 
Spring Willow put on in Shanghai, which are all included in Yang's list of seven plays. I have referred to a reprint of this book in 2008.

${ }^{14}$ Yang Cunren grew up in Guangdong province and was in primary school in his hometown until 1916. He did not arrive in Shanghai until 1927. Cf. 潮 汕乃至中国现代文学史一个不应回避也不能遗忘的名字一一杨村人 http://www.chaonan.gov.cn/cnNews.aspx?newsid=6017 (accessed Sep 23, 2017). Xu Muyun is from Xuzhou city, but went to Shanghai Datong University and stayed in Shanghai after graduation. It is not clear when he arrived in Shanghai. His brief biography can be found on the website of Xuzhou City's Literature and Art Association: http://www.Xzwyw.com/rencaixinxiku/2015-05-17/21.html (accessed November 4, 2017).

15自我演戏以来 [Since I Started to Perform Onstage]. In this memoir, Ouyang refers to Spring Willow's time as 15 years ago, which implies that it was written in 1929/1930.

${ }^{16}$ Lu Jingruo 陆镜若(1885-1915) was a lead member of Spring Willow Society, who, according to his fellow member Ouyang Yuqian 欧阳予倩, was very enthusiastic about performing Ibsen's A Doll's House and Wild Duck. See Ouyang (2014).

17 田汉 (1898-1968). Playwright. He wrote the lyrics to the Chinese national anthem.

18 阿英 (penname of Qian Xingcun 钱杏村) (1900-1977). A Ying was an influential dramatist and literary critic who joined the Chinese Communist Party in 1926. He and Yang Cunren were two of the co-founders of the proletarian revolutionary journal The Sun Monthly 太阳月刊 (1928-1929). ${ }^{19} 1956$ was the year when Ibsen's A Doll's House was performed for the first time in the People's Republic of China. A Ying's article attacks the initial Ibsen advocates such as Hu Shi for promoting bourgeois values through Ibsen's works. The original article was published in the official newspaper for culture and art- Wenyi Bao-in September 1956.

${ }^{20}$ A Ying was 13 years old in 1914. He was from Anhui province and did not come to Shanghai until 1927. Therefore it is unlikely that he saw the performance in question in 1914. Furthermore, he himself does not claim to have watched the performance.

21 This article is dictated by Lu and transcribed by Feng Shuluan 冯叔变 (1883-?), another member of the Spring Willow Society.

22 Eide has another essay "Performances of Ibsen in China after 1949" published in 1987 in Drama in the People's Republic of China.

${ }^{23}$ It appears that Eide sometimes equates wenming xi repertoire with the repertoire of Spring Willow Society, using them interchangeably. Based on Seto's research, Spring Willow was only one of the many wenming xi groups in China and their repertoire was much smaller than that of some of the other wenming xi groups. (See Seto [2006])

24 葛一虹 (1913-2005). Member of the Chinese Left-Wing Dramatist Alliance (1930-1936) - and author/editor of a few books on the history of Chinese spoken drama - was the head of the Huaju Research Institute at the Chinese National Academy of Arts from 1980 to 1987. He is considered an authority on the history of Chinese huaju. 
${ }^{25}$ A Ying's article in 1956 is quoted in Eide's 1983 essay as one of the Chinese sources that claim the first Ibsen performance in China to be Spring Willow's A Doll's House in 1914.

${ }^{26}$ This informant's name is Min Xiaosi 闵晓思, who wrote a short article on several early Nora performances in China that was published in Wenhui Bao (Wenhui Newspaper) in 1962.

${ }^{27}$ One possible reason for Eide's suspicion is that Yuan Ou 怨偶 contains a character ( $\mathrm{Ou}$ 偶) that is in the most common title for A Doll's House: Wan Ou Zhi Jia 玩偶之家. However, while they are the same character, they mean different things. "Ou" in Yuan Ou means a married couple, while "Ou" in Wan Ou Zhi Jia means puppet or doll.

${ }^{28}$ Yuan $\mathrm{Ou}$ is a tragedy of eight acts about a young woman who commits suicide because she is forced into a marriage with a man who abuses her. For the full synopsis and plot outline, see Zheng 1919, pp.5-6.

${ }^{29}$ This is an article containing three letters as responses to questions about foreign drama in China from three scholars - including Elisabeth Eide. The original questions are not published in this article.

${ }^{30}$ See Seto (1988-1990). Shenbao was a local newspaper in Shanghai - shen meaning Shanghai and bao meaning newspaper - that ran for 77 years from 1872 to 1949 . It has a long history of advertising theatre events and thus has become an important source for studying the theatre repertoire in China before 1949. See Huang (2016).

31 See Seto $(2001,2003)$ and Huang (2001).

${ }^{32}$ See Ouyang (2014).

33 空谷兰. Adapted from a Japanese novel.

34 红楼梦 [Dreams of the Red Mansion]

${ }^{35}$ Novel by Leo Tolstoy (1899).

${ }^{36}$ See Zhou (2014).

${ }^{37}$ See Wang (2011).

${ }^{38}$ For example, Fan (1914), Zhu (1914), Zheng (1919), and Zhu (1942).

${ }^{39}$ This volume presents seven new drama plays - of which four appear to be part of Spring Willow Theatre's repertoire and none was adapted from Ibsen's plays.

${ }^{40}$ This book gives a chronological account of the new drama history from 1899 to 1914. The account ends on May 5, 1914, when the six major new drama groups (including the New Drama Society) performed together at Min Ming Society's venue (81). Apart from the author's account of the history, the book also includes biographies of new dramatists, synopses of selected plays, and a few theatre reviews. Neither Ibsen nor any of Ibsen's plays is mentioned in this book.

${ }^{41}$ This book includes 99 Chinese new drama plays - some of which are adapted from foreign novels - and an additional 33 new drama plays from outside of China. Among the 33 foreign new drama plays, 20 are by Shakespeare and 7 are from Japan. None was by Ibsen.

${ }^{42}$ This book includes a list of 302 titles of new drama plays without plot summary. There is no apparent match for $A$ Doll's House in the titles. ${ }^{43}$ Huang's position on whether Lu played a role in $A$ Doll's House in Japan is unclear. She confirms that Lu's name is on the cast list, but then also claims that it is unknown whether Lu played a role in A Doll's House. Her 
research on Lu's activities in Japan seems to be based mainly on 中村忠 行’s《“春柳社”逸史稿》。

44 文艺协会

45 坪内逍遥

${ }^{46}$ Eide claims that she has collected information on about 25 performances

of Ibsen in China between 1920 and 1949, and 4 after 1949 (till 1997). I

have not seen any published list of hers where all of the 29 performances are listed. 7 of those are presented in her 1983 essay: 1914 A Doll's House in Shanghai by Spring Willow; 1925 A Doll's House in Beijing by Ershiliu Jutuan; 1927/1928 An Enemy of the People in Tianjin by Nankai Middle School; 1928 A Doll's House in Tianjin by Nankai Middle School; 1935 A Doll's House in Nanjing with Wang Ping as Nora, in Shanghai with Lan Ping as Nora. According to her, most of these performances are not welldocumented, with only rough dates and one or two of the cast members' names (Eide 1997, 199).

${ }^{47}$ It is mentioned in 中国话剧通史 [Comprehensive History of Chinese Huaju Art] (Tian 2008) that the first stage performance of Ibsen's plays in China is in 1923, by the Women's Normal College in Beijing (p.89).

However, on page 83 in the same book, the authors claim that Spring Willow Society performed A Doll's House in 1914 and that the performance "did not receive enough attention".

${ }^{48}$ Instead, Eide's informants refer to the performance of $A$ Doll's House by a group of students from Beijing Renyi Drama Special School 北京人艺戏 剧专门学校 in 1925 called Nian Liu Juxue She (Twenty-six Drama Studies Society). The year and location of this performance appear to be inconsistent in the accounts that I have read. It is possible that this group staged A Doll's House several times. But the most reliable source for this performance is what Tam has given in his 2001 book - a review written by Zhen Sheng on December 20, 1924, one day after the performance (Tam 2001, 198). The same date is given by Zhang Chuntian $(2013,165)$. According to Zhen Sheng, the play was staged in the YMCA in Beijing on December 19, 1924 (4).

${ }^{49} \mathrm{My}$ view on the first Ibsen performance in China is consistent with that of Seto's in his book A Study on the Formation of Chinese Spoken Drama. 2015. In my research, however, I have found another possibility of the first Ibsen performance in China, which lies in Zhu Shuangyun's list of early Chinese professional huaju repertoire in his 1942 book, where what seems to be Ibsen's The Pillars of Society 社会柱石 is included $(1942,60)$. But since there is no information on this title in Zhu's book other than that it is one of the "modern attire plays", it is difficult to say for sure that this was Ibsen's play. The Pillars of Society was first introduced to China by Hu Shi in his 1918 article "Ibsenism", where he calls it Shehui Dongliang 社会栋梁. And yet the title in Zhu Shuangyun's list is Shehui Zhushi 社 会柱石, the same as in its first Chinese translation by Zhou Shoujuan 周瘦鹃 in 1920 in the Short Story Magazine. Zhu's account of wenming xi history ends in 1926 (1942:55), and therefore it is likely that the staging took place sometime between 1920 and 1926. Spring Willow Society ended in 1915, so this Ibsen play would unlikely to have been in their repertoire. If this play in Zhu's list is indeed Ibsen's Pillars of Society, then this could well be the first Ibsen performance in China, provided it was performed before May 5, 1923. Unfortunately, I have not found any other account of this performance than the title mentioned in Zhu's book. Zhu's entire list is cited at the end of Yuan Guoxing's book (2000), with no additional information.

${ }^{50}$ The New Drama Fellowship is created by former Spring Willow members after they return to Shanghai from Japan. They performed under the name Spring Willow Theatre from 1914 to 1915 . See note 4. 
${ }^{51}$ Chen Dabei's 陈大悲 article “Amateur Theatre” 爱美的戏剧- first published in the Beijing Morning Post in 1921 and then turned into a monograph in 1922 - introduced the concept of "amateur theatre" based on a few books by American authors such as Sheldon Cheney's The New Movement in the Theater (1914), Emerson Taylor's Practial Stage Directing for Amateurs (1916) and William Lyon Phelps's The Twentieth Century Theater (1920). The Amateur Theatre was meant to be a direct answer to the problems of wenming xi by advocating for non-profit and nonprofessional theater. The effect of this movement reached many cities in China and lasted for about five to six years.

${ }^{52}$ Nuola by Luo Jialun and Hu Shi (1918), Kuilei Jiating by Chen Jia (1918), and Nuola by Pan Jiaxun (1921).

${ }^{53}$ See Sun 2016, 77-83.

${ }^{54}$ See Tian et al. 1920, 80-81.

55 中国话剧成立史研究 2015

${ }^{56}$ According to Kano Ayako, the first translation that Shimamura Hōgetsu did of A Doll's House was based on the first German stage script where Ibsen had written an alternative ending due to the request from the German producer. Even though he eventually used the original ending for his performance in 1911, the character Nora is "milder, gentler, exuding feminine sensitivity and sadness about her decision to leave her husband and children" (Kano 2001, 187-188).

57 民国日报 The Republican Daily, Oct 1920. http://shtm.sta.edu.cn/ztzs/sjz/mgshhj/1de5a3ee_8099_4043_ae4f_c1232fa9 7ba5.html

${ }^{58}$ The first full play that Spring Willow staged was an adaptation of Harriet Beecher Stowe's Uncle Tom's Cabin in Japan. This novel, although not a realist text in a genre sense, is a realistic portrait of slavery in America. It is also noteworthy that Spring Willow's very first complete production was adapted from a text written by a woman writer.

${ }^{59}$ For a discussion on George Bernard Shaw and Chinese feminism, see Kay Li (2016). 